\title{
Internationalisation at home for tourism training programmes: case studies from Vietnam
}

\author{
Cam Thi Hong Khuong \\ Department of English for Work and Settlement, Bendigo Kangan TAFE, \\ Bendigo, Australia, and \\ Ly Thi Tran \\ School of Education, Deakin University, Geelong, Australia
}

\begin{abstract}
Purpose - Tourism is one of the most notable features of the contemporary globalised world. The tourism industry is becoming increasingly vital to the economy of many developing and developed countries around the globe. The demand of the tourism industry has posed a challenge for tourism training providers to move towards a more responsive and internationalised curriculum to enhance work readiness for tourism graduates who are expected to work with an increased number of international tourists. The purpose of this paper is analyse whether and how internationalisation has been implemented in the tourism training programmes across six institutions in Vietnam.

Design/methodology/approach - The research deployed case studies as research strategy with interviews and document analysis as two instruments of data collection.

Findings - The major findings show that even though the tourism industry demands graduates to possess global competency, knowledge and skills, the curriculum does not prioritise the internationalisation dimensions and the faculty members are not facilitated to be internationally active in their roles. Overall, internationalisation is still fragmented and $a d$ hoc in these institutions even though the private institutions in this research appear to be more responsive to the trend of internationalisation in education than their public counterparts.

Research limitations/implications - The paper provides recommendations on how to effectively embed internationalisation components into local tourism training programs in Vietnam.

Originality/value - The research bridges the gap in the literature on internationalisation of the local tourism programme in non-English-speaking countries.
\end{abstract}

Keywords Internationalization, Graduate employability, English language teaching, Tourism curriculum, Vietnamese higher education, Vietnamese tertiary education, Vietnamese education,

Internationalization of the curriculum

Paper type Research paper

\section{Introduction}

In the era of globalisation with the "massive movement of people to virtually every corner of the world" (Wood, 1997, p. 2), Vietnam, a developing and non-English-speaking country in Southeast Asia endowed with numerous natural tourist attractions and being rich in culture and, less fortunately, with many battlefield sites, welcomes a significant number of international tourists each year. In 2013 alone, the country attracted over $7.5 \mathrm{~m}$ international tourists, particularly Chinese (25.2 per cent), South Korean (9.9 per cent per cent), Japanese (8 per cent),

(C) Cam Thi Hong Khuong and Ly Thi Tran. Published in Higher Education Evaluation and Development. Published by Emerald Publishing Limited. This article is published under the Creative Commons Attribution (CC BY 4.0) licence. Anyone may reproduce, distribute, translate and create derivative works of this article (for both commercial and non-commercial purposes), subject to full attribution to the original publication and authors. The full terms of this licence may be seen at http://creativecommons. org/licences/by/4.0/legalcode

The authors are grateful to the anonymous reviewers for their very helpful comments which help the authors considerably improve this paper. The authors also wish to thank the participants for the valuable contributions to this research.

Tourism training programmes

Received 15 January 2018 Revised 10 May 2018 Accepted 7 June 2018 
HEED

12,1

American (5.7 per cent), Taiwanese (5.3 per cent) and Cambodian (4.5 per cent), according to the Vietnamese General Statistics Office (2013). In addition to globalisation and regionalisation, tourism has become an important service export to Vietnam, generating US $\$ 7.3$ bn to the national economy in 2014. The direct contribution of travel and tourism to GDP in 2014 was US\$8.0 bn (4.6 per cent of GDP) (World Travel and Tourism Council, 2015, pp. 3-5).

Responding to the growth in this industry, on 30 December 2011 the Vietnamese Government made a formal decision (No. 2473/QĐ-TTg) regarding "Strategies to develop Vietnamese tourism up to 2020: a vision to 2030" (Nguyen, 2011). The document pointed out that in the lead-up to 2020, tourism will basically become the key industry in Vietnam requiring professionalism, comprehensive and modern systems of technical facilities and tourism products of good quality, variety and competitiveness. The government's goal is to grow the tourism industry aiming to achieve an average growth rate of 11.5-12 per cent per year in the period 2011-2020. This is to be achieved by welcoming 10-10.5 m international visitors and $47-48 \mathrm{~m}$ domestic tourists in 2020 with a total revenue of approximately US \$18-19 bn, contributing around 6.5-7 per cent of GDP growth and creating three million new jobs, of which 870,000 will be directly linked with tourism.

In line with the opportunities, the Vietnamese tourism industry is confronted with various challenges. The tour and travel services sector in particular has a deficiency in the number of qualified staff to meet the demand of the growing number of international tourists, especially tourism employees with intercultural and global competencies and high proficiency in foreign languages (Thao, 2012; Vi, 2010).

Accordingly, there is a critical need for tourism students to enhance their employability in the current tourism market with an exponential number of international tourists by developing adequate intercultural and global competence and a good command of English. Within this context, developing a more responsive and internationalised curriculum to facilitate the development of these capacities for tourism graduates is becoming crucial for tourism training institutions. Thus, the Vietnamese Government has taken several initiatives to improve the quality of tertiary education and provide qualified human resources for the globalisation era. Many policies have been passed for this purpose. The most comprehensive policy on higher education renovation is the Fundamental and Comprehensive Renovation of Higher Education, which is also called the Higher Education Reform Agenda (HERA), approved by the Cabinet in November 2005 (Resolution No. 14/2005/NQ-CP, 2005). The government emphasises the formulation of strategies of international integration, enhancement of cooperative capacity and competiveness of Vietnamese tertiary education (Government of Vietnam, 2005). In order to achieve this target, some proposed strategies are:

[...] teaching and learning in foreign language, particularly English for the immediate future; improving the quality of training programmes and research which are likely to attract foreigners; selectively learning the advanced training programmes in the world; reaching an agreement on equivalent qualification and cooperation with institutions in the world; encouraging joint training of high quality, exchanging of lecturing staff and foreign experts; encouraging Vietnamese lecturers to teach overseas; and increasing the number of international students in Vietnam.

The HERA agenda indicates that Ministry of Education and Training (MOET) aims to internationalise the Vietnamese education system to equip graduates for challenges in the globalised age. Furthermore, in the Strategy for Education Development for Vietnam 2011-2020, internationalisation is one of the eight initiatives fundamental to the development of Vietnamese education (MOET, 2012). However, these strategies have been criticised to exist mainly in rhetoric; and in practice, internationalisation activities at the institutional level are still fragmented, inconsistent and ad hoc (Tran et al., 2014).

There is an abundant literature on internationalisation of education in the world and Asian countries, yet previous studies mainly explored transnational/cross-border education 
as a form of internationalisation (Huang, 2007; Leask, 2015; Mok and Yu, 2013). Scant research has been conducted on internationalisation features embedded in local programmes in non-English-speaking countries like Vietnam, particularly in tourism training programmes to provide global competency for local students (Khuong, 2015). This shows the need for a systematic and multifaceted investigation into the internationalisation of tourism programmes to equip graduates for employment in the tourism industry with an increasingly internationalised tourist body. The study aims to investigate whether and how the selected tourism training programmes are internationalised in response to the thriving status of Vietnamese tourism industry and to the HERA with an increased focus on internationalisation as proposed by the Vietnamese Government. All future references to tourism refer only to tour and travel services, and do not include other areas of tourism such as accommodation or food and beverage services, etc.

The research was undertaken at six institutions which provide tourism training programmes across both the higher education and vocational education and training sectors in different regions of Vietnam. Drawing on both curriculum and website analysis and interviews with lecturers as well as institutional leaders, the study shows that most institutions do not accord an adequate emphasis on the development of intercultural and global competency for tourism students, despite the demand for them to work in a globalised context and to interact with a growing number of international tourists in their prospective careers in the tourism sector. Thus, there seems to be a contradiction between the curriculum focus and the demand of the tourism labour market in Vietnam. This tends to undermine graduates' work readiness and place them in the position to "learn on the job" once commencing their professional role as tour and travel service personnel. But interestingly, overall, the private institutions examined in this study appear to be more responsive to the demand of internationalisation and developing graduate global competency than their public counterparts. This is largely due to their advantages in finance and resources as well as their institutional strategic policy.

\section{Internationalisation of education: definitions, significance and key factors}

Internationalisation is considered as "the process of integrating an international, intercultural, or global dimension (e.g. a perspective, activity or programme) into the purpose, functions or delivery of postsecondary education" (Knight, 2003, p. 2) to produce graduates who can function effectively in increasingly culturally diverse environments such as the tourism industry. Haigh (2002) explains in detail the significance of this process by arguing that this idea can enable students to develop: global and inclusive thoughts to consider issues from various angles; a grasp of the fundamental tenets of intercultural viewpoints; an awareness of their own cultural traditions and perspectives in relation to other cultures and their perspectives; and an appreciation of the relation between their academic disciplines locally and globally. Black (2004) and Hobson and Josiam (1996) agree that graduates who are in contact with clients from various nationalities and cultural backgrounds (such as those who work in the tourism industry) will need the knowledge and skills that enhance their capability to adapt to a foreign culture and to operate in a socially and culturally diverse environment.

Knight (2003) divides a process of internationalisation into two streams: internationalisation at home and internationalisation abroad. The first stream provides students with international understanding and intercultural skills on campus. The second stream operates similarly but requires the movement of the people or programmes across national boundaries. Such categorisation also highlights that internationalisation in education comprises both people and learning activities. Several researchers have categorised elements contributing to the internationalisation of education with recognition 
HEED

12,1

of both schemes. Black (2004) includes four elements in her international classification scheme as follows:

(1) faculty: exchange, international joint research and consultancy;

(2) students: exchange, double degree programmes, joint international programmes;

(3) curriculum content: internationalising courses, adding international courses, adding languages, work or study abroad; and

(4) international alliances: faculty exchange, student exchange, double degree or joint degree programmes.

Brookes and Becket (2009), however, are critical of Black's framework, noticing some overlap between these elements. For example, in hospitality programmes students are often required to undertake international work placements. These elements are also inter-related as international courses can be informed by international research or consultancy and adding languages to the curriculum can facilitate international study exchanges which can lead to the forming of international alliances. Brookes and Becket (2009) then classify internationalisation into seven key dimensions, consisting of:

(1) internationalisation of the curriculum;

(2) internationalisation of the student experience;

(3) international recruitment;

(4) international partnerships and strategic alliances;

(5) international exchanges (staff and student);

(6) international research; and

(7) alumni relations.

Nevertheless, overlap also exists within the framework that Brookes and Becket (2009) proposes regarding the placement, which is the same indicator in both dimensions: the internationalisation of the student experience and international exchanges. Similarly, activities in international partnerships also resemble those for staff in international exchanges.

Based on Black's model, Sangpikul (2009) develops a framework for internationalisation of Thai hospitality and tourism programmes with some localised elements that encompass:

- faculty: staff recruitment and human resource development, staff professional development;

- students: student-oriented approach, activity-oriented approach;

- curriculum development: infusing international dimensions into existing courses, adding international/multicultural courses to the curriculum, offering degrees in international hospitality and tourism management, developing joint programmes with foreign universities; and

- international alliances: faculty, students, curriculum and other activities.

All these frameworks identified elements of both internationalisation at home and abroad. Within the scope of this study, which focusses on internationalising education aimed at enhancing global competency and intercultural capability for local Vietnamese students, the internationalisation at home was mainly investigated. Furthermore, according to Wright and Lander (2003), the presence of international students alone does not constitute the internationalisation of education. The elements related to international students are, 
therefore, also beyond the scope of this study. To put it simply, this paper focusses on investigating the internationalisation process of Vietnamese tourism training programmes in two main domains: curriculum and lecturing staff. In Vietnam, internationalising the curriculum has been identified as one of the primary vehicles to help the higher education system improve its quality and catch up with the regional and international developments in teaching and learning (Hoang et al., 2018; Tran and Marginson, 2018; Tran et al., 2018.

\section{Internationalisation of the curriculum}

The central role of internationalisation of curricula in practically shaping students' international and intercultural perspectives and ensuring global learning outcomes is brought into focus by numerous researchers (Black, 2004; Haigh, 2002; Hobson and Josiam, 1996; Leask, 2001, 2015). Leask (2001) states, "internationalising university curricula is a powerful and practical way of bridging the gap between rhetoric and practice" (p. 100). In her latest book, Leask offers an advanced definition of internationalising the curriculum taking into account comprehensive dimensions of university teaching, learning and services. Leask (2009) considers internationalisation of the curriculum as a process of incorporating international, intercultural and global dimensions into the content of the curriculum as well as the learning outcomes, assessment tasks, teaching methods and support services of a program of study (p. 209, italics added).

Internationalisation of curriculum can refer to the inclusion of varied activities such as study abroad programmes, foreign language courses, interdisciplinary or area programmes or the provision of programmes or courses with an international, intercultural, or comparative focus. From a study conducted by Bremer and Van der Wende (1995), the following features of internationalised curricula are considered essential by department heads: studies of professional practices in other nations or cultures; learning about transnational knowledge; requiring students to complete studies in a foreign language or in areas such as intercultural communication or international studies; training in cross-cultural communication and skills; application of other countries' experiences to local issues; discussion of global issues and international affairs; studies on international case studies; and parts of courses delivered by foreign scholars in departments and schools.

Several approaches to internationalisation of the curriculum have been suggested by researchers. A simple approach adopted by many institutions that lack trained lecturing staff to teach internationalised courses, is to add international materials, particularly examples, to existing courses, according to Akhter and Ahmed (1996). Using this fundamental method, lecturers explain a concept and then take both domestic and international examples to illustrate its application. An example of this application was also put forward by Akhter and Ahmed (1996) who suggested negotiating strategies can be illustrated through the difference in Japanese and American negotiating styles. Different from the Japanese who normally spend some time getting to know their counterparts in the initial stage of negotiations, Americans generally get straight to the point. As a result, negotiations may break down due to cultural misunderstanding.

According to Guerin (2009, p. 612), internationalising curricula is mainly obtained by "the infusion of international modules, especially in consortia of community colleges dedicated to enhancing international education." Edwards et al. (2003) suggest three levels of internationalising curricula: Level 1 is including international examples, cases and perspectives in the curriculum; Level 2 is creating cross-cultural interaction in formal and informal situations; and Level 3 is immersing students in global settings through foreign language study and exchange programmes.

Internships can be a truly international feature of an internationalised programme (Black, 2004). This supervised work experience, if conducted in another country and 
HEED

12,1

sustained over a minimum period of 20 weeks, will provide students with a genuine international experience. Students can gain an in-depth knowledge of another culture, have tourism industry experience in different cultures, create industry networks and prepare for international careers in the hospitality and tourism industry (Black, 2004; Sangpikul, 2009).

\section{Internationalised faculty}

24 An internationalised curriculum can only be optimised if it is synchronised with the internationalisation of faculty members as they play a pivotal role in an institution's internationalisation process (Tran and Le, 2018). Just as internationalisation of curriculum is in the spotlight of research, so academics are being given more and more attention in the literature (Bedenlier and Zawacki-Richter, 2015; Criswell and Zhu, 2015; Friesen, 2012). The role of faculty members has changed significantly over the years, "moving from teaching, to service, and then research, reflecting shifting priorities both within the academy and beyond" (Boyer, 1990; as cited in Criswell and Zhu, 2015, p. 23). As organisations are moving forward to the internationalisation trend, faculty members are required to be dynamically responsive (Criswell and Zhu, 2015).

In order to function effectively and appropriately in an international and cross-cultural environment, faculty members are expected to possess intercultural capability in order to make their students globally competent and prepare them for an intercultural workplace. The first core element of the process of developing intercultural competence, according to Deardorff (2009), is that academics are required to have the right attitudes which encompass intrinsic motivation for teaching internationally and openness to other cultures. Second, lecturing staff need to understand the importance of foreign language competency. In this case, English language is considered crucial in an international environment as it has achieved a genuinely global status and is recognised almost in every country (Duong and Chua, 2016; Tran and Nguyen, 2018). Thus, faculty members who master the English language will feel more comfortable with cross-cultural teaching experiences.

Some strategies to internationalise faculty staff have been suggested by scholars. Based on the model of intercultural competence of Deardorff (2009), Gopal (2011) puts forward that lecturing staff can obtain intercultural competence by virtue of emerging themselves in a new cultural environment and attending professional development through seminars, role-playing, case studies, invitational dialogue and other exercises pertaining to cross-cultural contexts or topics. Black (2004) proposes encouraging staff to engage in different international activities such as international conferences, acting as visiting lecturers in foreign institutions or joint research projects with foreign researchers. Sangpikul (2009) suggests providing staff with opportunities to further their studies at higher levels such as master's or PhD programmes by granting overseas scholarships for their existing staff to obtain higher knowledge and experience in an international environment. Dang et al. (2013) support the employment of the overseas-trained lecturers. Lecturing staff with international experience contribute to students' learning and curriculum development since they can share their knowledge, opinions and experiences with students and other faculty members (Black, 2004). All these experiences (e.g. overseas study, international work experience) dealing with international issues that the lecturers have addressed will help improve their own intercultural competence (Gopal, 2011), which entails enrichment of the students' international knowledge through classroom delivery (Sangpikul, 2009). Finally, institution can internationalise their faculty by recruiting foreign lecturers to the permanent teaching staff (Black, 2004). This strategy advocates what Altbach and Yudkevich (2017, pp. 8-10) highlights that "international faculty are a growing and increasingly important part of the global academic labour force, bringing diversity, new perspectives, and skills wherever they go." 


\section{Methodology}

The research addresses whether and to what extent tourism training programmes in Vietnam are internationalised in response to the needs of the Vietnamese tourism industry and to the increase emphasis on internationalisation by the Vietnamese Government's HE agenda. The case study approach was chosen to be the main research method because it is the most widely employed method throughout the field of education (Gall et al., 2007; Grady, 1998; Merriam, 1998) and is suitable to the aims and nature of this research. The multiple case study approach was selected here to gain a nuanced understanding of the multifaceted aspects and distinctive nature of different types of institutions which are involved in providing tourism training programs across different regions in Vietnam. It was designed based on "the logic of replication" in which the researcher replicated the procedures for each case (Creswell, 2007, p. 74). There was a total of six case studies representing different types of tourism training institutions in Vietnam. Of these, three were public vocational colleges (Institutions A, B and C) under the management of Ministry of Labour, Invalids and Social Affairs (MOLISA). One was a public university (Institution D), and two were private universities (Institutions E and F) under the management of the MOET. The terms "public" and "private" universities or vocational colleges will be used to refer to institutions in public and private sectors, respectively. These institutions were selected to represent a diversity of education forms managed by different authorised ministries and operating in different ways (Hayden and Lam, 2010).

In terms of governance, universities are under the management of MOET while vocational training colleges are managed by the General Department of Vocational Training, a department of MOLISA. The vocational training curriculum priotises the development of technical and specialised skills, knowledge and competencies for a particular profession while university curriculum is often oriented towards more theoretical knowledge. Besides the two key players in academic quality assurance (i.e. MOET and MOLISA), public universities and vocational colleges are also under tight control of line management from other ministries. In this case, the tourism vocational colleges are also managed by the Ministry of Culture, Information and Tourism. Private institutions are responsible to the state through their individual governing boards who, most of the cases, are people-founded, and the members of governing boards elected or appointed by the shareholders responsible for the establishment of the institution. Financially, public universities and colleges are mainly funded by the state government and receive additional contribution from the students. The private institutions, on the contrary, are substantially self-funded by means of charging tuition fees. They are more financially autonomous than their government counterparts, thus are able to allocate funds to areas that accommodate the demands of their students and staff.

Interviews, as described by Guba and Lincoln (1981), are "the very backbone of field and naturalistic research and evaluation" (as quoted in Clarke and Dawson 1999, p. 71). This technique can help the researchers learn "how people construct the realities - how they view, define, and experience the world" (Taylor and Bogdan, 1998, p. 110). The academic groups to be interviewed included the faculty leaders, tourism lecturers and foreign languages lecturers. Only three deans of Institutions A, E and F were available for interviews. In Institution B, no dean had been appointed and in Institutions C and D, the deans were away on business. Therefore, three deputy deans were invited for interviews in their place. The aim of interviewing these leaders was to gain an insight into elements of internationalisation within the curricula. Furthermore, the interviews with these key figures in the academic field provided access to important documents for this study, i.e., the specific aspects of internationalisation encompassed in the curricula of the tourism training programme in each institution. Interviews were then conducted with 15 lecturers in the tourism specialisation and 11 English lecturers.

Document analysis was employed as another method of data collection because its main merit is its "clear, tangible record" (Grady, 1998, p. 24). The data collected by this method are 
HEED

12,1

also named as "artefacts" (Goetz and LeCompte, 1984, p. 153) since they are the "products of a given context and are grounded in a real world" (Merriam, 1998, p. 109). This characteristic means that the collection of such data brings profound insights to the study. The artefacts employed in this project were the current situations of internationalisation in the curricula of the tourism programmes of the selected universities and colleges. The full curricula of Institutions C, D and F were taken from the websites. Those of Institutions A and $\mathrm{B}$ were obtained thanks to the personal relationship of one of the researchers with the lecturers and the training departments. Unfortunately, only a part of the curriculum of Institution $\mathrm{E}$ was made available on its website. Except for the curriculum of Institution $\mathrm{F}$, all of the collected curricula were written in Vietnamese, and were then translated into English by one of the researchers for the purposes of analysis.

Because the multiple case studies method was used, this research based its analytical framework on the theory of comparative case study analysis, which consists of "two stages of analysis - the within-case analysis and the cross-case analysis" (Merriam, 1998, p. 194). For the within-case analysis, each case study was analysed as earlier described. Based on the within-case analysis, the cross-case analysis was conducted. According to Miles and Huberman (1994), researchers employ cross-case analysis to see "processes and outcomes that occur across many cases, to understand how they are qualified by local conditions, and thus develop more sophisticated descriptions and more powerful explanations" (as cited in Merriam, 1998, p. 195). In order to have a comprehensive picture of the WIL initiatives in the tourism training programs in Vietnamese tertiary institutions, the cross-case study analysis was carried out by comparing and contrasting the data collected from each case study.

Only a small number of excerpts from the interviews are presented here due to the scope of the paper, and to construct and illustrate the key arguments rather than to exhibit the broad spectrum of interviewees. The key aspects which this paper focusses upon and the relevant quotes were identified through a thorough process of coding. The audio recordings of the interview data were listened to several times for themes and sub-themes. All the quotes employed as illustrations were translated into English by the researchers. To protect the confidentiality of the participants, their names and institutions are kept anonymous through the use of pseudonyms.

\section{Tourism lecturing staff in response to the internationalisation trend}

This section provides an overview picture of the faculty members, encompassing their qualifications, levels of foreign language proficiency, research activeness and other activities pertaining to their responsiveness to the internationalisation trend of the training organisations and also the hurdles they encounter on the way to develop their intercultural competence as proposed by Deardorff (2009).

At the time of the research was carried out, the tourism faculties of these institutions were staffed by a total of 81 lecturers. Over one-third of the teaching staff had bachelor degrees, half had obtained their master's degrees and approximately 15 per cent held PhDs. Among the six examined institutions, Institution $\mathrm{F}$ had the most credentialed team of lecturing staff with seven $\mathrm{PhD}$ holders, three of whom were foreign lecturers.

Across a total of 32 participants, almost all (31/32) had earned their highest qualifications in a field related to their teaching areas, but less than one fourth (9/32) had obtained their qualifications overseas. The lecturers in the government institutions who had gained their academic and professional training overseas were outnumbered by those from the private institutions. As the dean of Tourism Faculty in Institution A disclosed, "financial issues were the main hurdles for the college lecturers to pursue study in a foreign country". Compared with the lecturers in the private institutions, the government teaching staff was less well off financially due to their lower salaries. A government employee earns between US\$145.25 and US\$652.50 monthly depending on one's seniority in the organisation, according to the 
pay sheets provided by the finance department of Institution A. They thus had hardly any opportunities to earn qualifications overseas without being subsidised. In addition, this salary is below a living wage in the fast-developing Vietnam. Therefore, many academics must resort to "finding second and third jobs in order to makes ends meet" (Hoai, Institution B), which might lead to their primary responsibilities at colleges being compromised. This resonates what Tran et al. (2014) who argue that the poor level of remuneration is one of the key reasons for the lack of faculty quality and faculty commitment in Vietnam, including the commitment to improving and internationalising teaching and learning as well as closing the gap between the curriculum and the labour market.

The lecturers from the private institutions compared favourably with their counterparts in the public sector regarding the level of foreign language proficiency since they had experience in the particular countries where their qualifications were granted. In Institution F, the lecturers' proficiency in English was even more important because the university had launched a programme in which English was the medium of instruction from 2012, according to the dean in this institution. Professional development activities aiming to enhance the English proficiency of the staff were implemented. The government lecturers, however, were also made aware of the importance of foreign languages and were self-motivated in upgrading their language proficiency. Specifically, the lecturers in Institution B had degrees in both the tourism area and in a foreign language. They also claimed to be able to deliver tourism subjects in this foreign language. In Institution C, many of the tourism lecturers had enrolled in a master's course, which required them to achieve an IELTS score of at least 4.5 to be accepted into the programme. Therefore, they could comprehend basic English. These lecturers' initiatives present their intrinsic motivation and awareness of the importance of foreign language as per proposal of Deardorff (2009). However, in terms of foreign language, lecturers in Institution A were the least proficient and there had been no activities to encourage them to upgrade their learning.

While the universities offered more opportunities and an appropriate environment for their lecturers to do research, the research skills of lecturers in the colleges were rather limited. A lecturer in College $\mathrm{C}$ admitted:

The lecturers are rarely interested in conducting research. Just those who are pursuing a Masters program have an impetus to do research for the sake of their own study (Uyen, Institution C).

National and international conferences and seminars were frequently organised in Institutions $\mathrm{D}, \mathrm{E}$ and $\mathrm{F}$. University $\mathrm{D}$ published one academic journal quarterly to promote research activities. In Institution $\mathrm{F}$, a department of scientific research had been established to support the research initiatives of its staff and students. In contrast, the colleges were inactive in this area with limited research projects being implemented. One justification that the lecturers in the college gave for their inability to improve their research skills was their excessive teaching workloads. Due to staff shortages, the current staff in four institutions (Institutions A, B, C and F) were confronted with heavy teaching loads which exceeded the standard teaching hours per academic years, which normally ranged from 280 to 510 depending on the seniority of the lecturer. The lecturers were assigned to teach various subjects, even those outside their expertise, as in Institutions C and F.

The findings indicate that the lecturers in the colleges responded slowly to the internationalisation trend compared with those in the universities, particularly the private ones. A majority of them lacked international experience such as overseas study, research activeness, attendance at international conferences or international work experience and industry exposure, which is against what Black (2004), Gopal (2015) and Sangpikul (2009) suggested and will impinge negatively on their development of intercultural competence (Deardorff, 2009). The private university lecturers, due to their financial strengths and institutional resources, had more opportunities to engage themselves in international activities. 
HEED

12,1

Table I.

Summary of outcomes of the investigated programmes
Institution F, particularly, was an outstanding activist in the internationalisation of education when it attracted foreign lecturers to join the permanent lecturing team as suggested by Black (2004) and its prioritisation of the development of global competency for students.

\section{Internationalisation elements in tourism training curricula}

Outcomes of tourism programmes

All six institutions advertised the claimed outcomes for their graduates. Table I presents the summary of the outcomes of the programmes in this study.

As shown in Table I, all of the six institutions promised to equip their students with general knowledge of tourism, generic skills and foreign languages. Three vocational colleges also offered skills in the tour guiding programmes. This unity is due to the common training plan approved by MOLISA applicable to all vocational colleges within the system. University $\mathrm{D}$ focussed on managerial skills in business in general and in tourism in particular and paid no attention to specialised knowledge and skills in tour guiding. Institutions $\mathrm{E}$ and $\mathrm{F}$ included graduate outcomes in both specialist knowledge and skills in tour guiding-which are the strengths of vocational colleges - and managerial skills in business and tourism, which university programmes in the tourism field normally cover. In government institutions, except for the inclusion of foreign language teaching in the programme, other elements of internationalisation such as studies of professional practices in other nations or cultures, learning about transnational knowledge or training of cross-cultural communication and skills in the curriculum were not given sufficient attention in the programme.

University $\mathrm{F}$ was the only institution that highlighted the global perspectives as one of their outcomes. This specific outcome was embedded in several subjects in the curriculum, namely, "Customer services in a global environment", "Intercultural communication, project of tourist psychology" and "Global tourist system". To achieve this aim, this institution incorporated various international alliances into the programme. The highly qualified lecturing staff from multicultural backgrounds, and in particular their being bilingual in both Vietnamese and English, gave it a significant advantage over state owned and other private tourism training institutions. Furthermore, this university had an impressive and professional website written in Vietnamese, English and French, intentionally designed for international web users. Also, an innovative curriculum which offered English as a medium of instruction for the majority of subjects was another highlight of internationalisation in this university. Some new subjects at this university had also been created based on the curricula of similar programmes from universities in other parts of the world together with ideas contributed by tourism companies.

\section{Foreign language teaching and learning}

English prevailed in all of the six tourism training institutions as the main foreign language. The second foreign language to be taught was French in Institution B. The lecturing staff in Institution B agreed that the attention to French was limited, since

\begin{tabular}{l} 
Outcomes \\
\hline General knowledge about tourism \\
Specialist knowledge about tour guiding \\
Skills in tour guiding presentation skills \\
Managerial skills in business and tourism \\
Generic skills \\
Competency in foreign languages \\
Global perspectives
\end{tabular}


the allocated time for it only sufficed to provide students with basic French knowledge to create simple exchanges.

Positive findings emerge when two private institutions are investigated. Institution $\mathrm{E}$ offered both English and French as core subjects. For the students who selected French, they were enrolled in an affiliate programme between this university and a famous university in France. Though they paid twice the tuition fees for this scheme in comparison with those for a regular programme, they received substantial benefits. They were in a smaller class with approximately 25 students, rather than in a regular class with up to 50 students. They also had more opportunities to be taught by native teachers from the Agence Universitaire de la Francophonie (Francophone Universities Association) to improve their communication skills in French. In particular, they would be granted a double degree on their graduation, one by the host university and one by the affiliated internationally recognised university in France. This offered the students more choices in their career pathway after graduation.

In Institution $\mathrm{F}$, the students were required to achieve a satisfactory outcome equivalent to 650 TOEIC points to be eligible for graduation. Furthermore, since 2012 the major subjects had been compulsorily taught in English. Therefore, according to the dean, it is the students' duty to equip themselves with English competence in the first and second year to be able to continue the rest of the course in English. In response to the university's policy of offering English-medium tourism programmes, the lecturers' proficiency in English was particularly taken into consideration. For the subjects in tourism, hotel and restaurant disciplines, however, it is hard to find lecturers with qualified English proficiency. Therefore, there was a requirement that the lecturers upgrade their English proficiency themselves in a given period of time to meet the standard of the university to maintain their position. The faculty also supported them by organising an English class taught by foreign teachers for them to enrol. An English centre was established to facilitate the English learning of the local students. According to the website, an English programme had been designed particularly for university students of all majors at different levels corresponding to the students' levels based on their programme of study and measured by placement tests on entry.

The findings point out that the autonomy of private institutions plays a substantial role in accommodating staff and students' needs, which resonates what Hayden and Lam (2010) depict about the Vietnamese higher education system. These training providers are capable of taking initiatives to either establish partnership with other overseas institutions to enhance students' foreign language competency or incrementing students and staff's language proficiency through further in-house training without any obstacles. In contrast, the role of foreign languages in the four public institutions received less attention from the lecturers and leaders than in the two private ones. In particular, in the three government colleges - due to the Tourism Law which did not allow college graduates to work as international tour guides-English as a foreign language was not highlighted. The ambivalence towards this subject was most clearly expressed by a lecturer in Institution B:

English language is allocated too many periods while it is not useful for the students after graduation because the college graduates are not allowed to guide international tourists, according to Vietnamese Tourism Law (Hung).

The lecturers in Institutions B and C admitted that this subject was given sufficient, not to say excessive, time but disappointingly, they were also unable to improve their students' English proficiency. This reflects that once a person lacks "intrinsic motivation" as Deardorff (2009) puts forward, they will not be able to enhance their intercultural competence, which in this case is embedded in their foreign language competency.

However, the allocation of time for English, especially English for tourism, in the programmes was thought to be inadequate in Institution D. In this institution, general English was allocated seven credits equivalent to 105 periods and English for tourism with three 
HEED

12,1

credits, equivalent to 45 periods for the whole programme. According to Tan, "This amount of time is not adequate for the students to acquire sufficient vocabulary, structures and proper pronunciation, let alone improve the four skills required to be confident in communication". Tu added, "We suggested increasing the amount of time for English, but the university's policy is to let the students improve their English outside in English language centres. This is beyond our control, so we have to accept that". In this case, the lack of students' practice due to the restriction of the government curriculum framework as Hayden and Lam (2010) reveals contributes to the unsatisfactory learning outcome of the students.

\section{Other features of an internationalised curriculum}

The interview data revealed that the lecturers showed negligence in providing the students with elements of internationalisation through their comments about the lack of translated materials in Vietnamese:

Only English or French materials are available but they are not useful due to the students' weak reading comprehension skills in foreign languages and due to the different viewpoints of the authors of these materials which are not suitable for a Vietnamese context (Dong, Institution D).

Even the lecturers in Institution $\mathrm{F}$, which was the most active in the internationalisation process concerning the quality of staff and curriculum design, complained about a shortage of materials for tourism specialisation written by Vietnamese authors. Therefore, the lecturers had to compile various resources, especially with reference to the materials from overseas institutions or from pioneers in tourism training. However, for the subjects which were new to the Vietnamese tertiary education such as heritage, advertising, and restaurant and hotel brand names, the documents in these areas were almost all in English or other foreign languages. The use of such foreign materials was somewhat disadvantageous to both the lecturers and the students according to Chan and Thang. Chan explained these drawbacks as follows:

The knowledge that foreign authors convey in these materials are not completely suitable to the Vietnamese context because the way foreign people deal with tourism issues such as advertising and serving customers in their tourist destinations is different from what Vietnamese people normally do. As a consequence, some knowledge is even beyond the lecturers' understanding and impossible to transmit to the students.

Thang added, "The language barrier in these materials may cause misunderstanding and hinder the students from grasping the full ideas of the authors". One solution they applied was to summarise the key points from the foreign books, then combine them with the ideas taken from Vietnamese materials together with the lecturers' real experience to produce in-house materials.

The lecturers' insistence on giving the students Vietnamese materials or the translation of foreign resources would hinder the development of global perspectives and engagement with foreign languages. The availability of foreign materials was, in fact, advantageous in providing an international context for the students to learn about other cultures and has the potential to assist with increasing students' intercultural awareness through interacting with the other cultures in its authentic languages.

Internships were a compulsory component in most of the tourism curricula. The students were sent to local tourism companies for approximately one to four months rather than overseas for their placements. During the internships, the students were largely requested to deal with local tourists or to perform menial administrative tasks. Hardly were they given opportunities to work with international customers:

Our students have barely been assigned with specialised tasks, let alone guiding international tourists. As far as I am concerned, many companies just gave students errands to run such as photocopying, distributing leaflets or carrying luggage for tourists (Vi, Institution $\mathrm{C}$ ). 
Tellingly, Institution $\mathrm{F}$ was a distinguished training provider in this regard when they affiliated with an overseas organisation to provide their students opportunities to undertake their placements in a foreign country in the South East Asian region such as Thailand, Singapore and Cambodia.

Though tourism curricula are central in equipping students with international and intercultural perspectives (Black, 2004; Deardorff, 2009; Haigh, 2002; Hobson and Josiam, 1996; Leask, 2001, 2015), global competences or intercultural competence were not given appropriate emphasis in the outcomes of most of the training programmes. Even the simplest approach recommended by Akhter and Ahmed (1996) that international materials should be added into the existing curriculum was not applied. The lecturers, on the contrary, attempted to translate foreign materials to facilitate the understanding of their students. The majority of tourism programmes were, thus, delivered in Vietnamese, and foreign language was only a subject. Therefore, the students mostly learned about language, rather than using foreign languages to achieve their communication purposes. Exceptionally, Institutions $\mathrm{E}$ (through its affiliated programme with a French institution) and $\mathrm{F}$ provided courses instructed in a foreign language, which meets the requirement of an internationalised curriculum as suggested by Black (2004), Bremer and Van der Wende (1995), Sangpikul (2009) and Edwards et al. (2003). Finally, internships were considered an opportunity for students to engage in an international environment as proposed by Black (2004) and Sangpikul (2009). The findings, however, indicate that the internationalisation was only theoretical in most programmes, again apart from Private Institution F.

\section{Conclusion}

This study sought to examine the internationalisation elements of six tourism training programmes in both the higher education and vocational education training sectors in Vietnam. The ultimate aim was to see whether these programs prepare students with global competence to serve international tourists effectively in the context of a growing Vietnamese tourism industry and where the Vietnamese Government launches the HERA to promote internationalisation of education. A case study approach was employed to investigate six tourism training providers. The instruments of data collection included document analysis from the tourism training curricula and the websites of the institutions along with the interviews of the lecturing staff.

The results showed that two main elements of an internationalised programme, including the lecturing staff and the tourism curricula, in the government institutes barely inculcated international perspectives in the tourism graduates, as outlined by previous researchers (Black, 2004; Haigh, 2002; Hobson and Josiam, 1996; Leask, 2001), in comparison with those in the private training providers.

For the quality of tourism training programmes to be able to equip graduates with global competences to be work-ready in an international environment, the following recommendations for tourism training providers are put forward based on the findings of the study:

- establish and maintain international alliances and international partnerships to assist with the integration of international dimensions into the curriculum and to create international placement opportunities;

- work with local tourism companies to create internship fieldwork opportunities in which students can work with international tourists rather than only with local tourists;

- provide professional learning to staff and engage them in ongoing professional learning with regard to internationalising the curriculum content and methods; 
HEED

12,1

\section{References}

Akhter, S.H. and Ahmed, Z.U. (1996), "Internationalizing business curriculum", Journal of Transnational Management Development, Vol. 2 No. 1, pp. 1-12, doi: 10.1300/J130v02n01_01.

Altbach, P.G. and Yudkevich, M. (2017), "Twenty-first century mobility: the role of international faculty", International Higher Education, Vol. 90, Summer, pp. 8-10, available at: https:// ejournals.bc.edu/ojs/index.php/ihe/article/view/9995/8695

Bedenlier, S. and Zawacki-Richter, O. (2015), "Internationalization of higher education and the impacts on academic faculty members", Research in Comparative \& International Education, Vol. 10 No. 2, pp. 185-201.

Black, K. (2004), "A review of factors which contribute to the internationalization of a programme of study", Journal of Hospitality, Leisure, Sport \& Tourism Education, Vol. 3 No. 1, pp. 5-18, doi: 10.3794/johlste.31.51.

Bremer, L. and Van der Wende, M. (1995), Internationalising the Curriculum in Higher Education: Experience in the Netherlands, The Netherlands Organisation for International Co-operation in Higher Education, The Hague.

Brookes, M. and Becket, N. (2009), "An investigation of the internationalisation of UK hospitality management degrees", Journal of Hospitality \& Tourism Education, Vol. 21 No. 3, pp. 17-24, doi: 10.1080/10963758.2009.10696948.

Clarke, A. and Dawson, R. (1999), Evaluation Research, Sage, London.

Creswell, J. (2007), Qualitative Inquiry and Research Design: Choosing Among Five Approaches, Sage, Thousand Oaks, CA.

Criswell, J.R. II and Zhu, H. (2015), "Faculty internationalization priorities", Forum for International Research in Education, Vol. 2 No. 1, pp. 22-40.

Dang, T.K.A., Nguyen, H.T.M. and Le, T.T.T. (2013), "The impacts of globalisation on EFL teacher education through English as a medium of instruction: an example from Vietnam", Current Issues in Language Planning, Vol. 14 No. 1, pp. 52-72, doi: 10.1080/14664208.2013.780321.

Deardorff, D.K. (2009), The Sage Handbook of Intercultural Competence, Sage Publication, Inc., Thousand Oaks, CA.

Duong, V.A. and Chua, C.S. (2016), "English as a symbol of internationalization in higher education: a case study of Vietnam", Higher Education Research \& Development, Vol. 35 No. 4, pp. 669-683, doi: 10.1080/07294360.2015.1137876. 
Edwards, R., Crosling, G., Petrovic-Lazarovic, S. and O’Neill, P. (2003), "Internationalisation of business education: meaning and implementation", Higher Education Research and Development, Vol. 22 No. 2, pp. 183-192.

Friesen, R. (2012), "Faculty member engagement in Canadian university internationalization: a consideration of understanding, motivations and rationales", Journal of Studies in International Education, Vol. 7 No. 3, pp. 209-227, doi: 10.1177/1028315312451132.

Gall, M., Gall, J. and Borg, W. (2007), Education Research: An Introduction, 8th ed., Pearson Education, New York, NY.

General Statistics Office (2013), "International visitors to Vietnam in December and 12 months of 2013", available at: www.vietnamtourism.gov.vn/english/index.php?cat $=012040 \&$ itemid $=5143$ (accessed 6 March 2014).

Goetz, J. and LeCompte, M. (1984), Ethnography and Qualitative Design in Educational Research, Academic Press, New York, NY.

Gopal, A. (2011), "Internationalization of higher education: preparing faculty to teach cross-culturally", Journal of Teaching and Learning in Higher Education, Vol. 23 No. 3, pp. 373-381.

Government of Vietnam (2005), "Fundamental and comprehensive reform of higher education in Vietnam 2006-2020", 14/2005/NQ-CP, 2005, Hanoi, available at: http://moj.gov.vn/vbpq/Lists/ Vnbnphplut/View_Detail.aspx?ItemID=17258 (accessed 21 June 2014).

Grady, M. (1998), Qualitative and Action Research: A Practitioner Handbook, Phi Delta Kappa Educational Foundation, Bloomington, IN.

Guerin, S. (2009), "Internationalizing the curriculum: improving learning through international education: preparing students for success in a global society", community college Journal of Research and Practice, Vol. 33 No. 8, pp. 611-614.

Haigh, M. (2002), "Internationalization of the curriculum: designing inclusive education for a small world", Journal of Geography in Higher Education, Vol. 26 No. 1, pp. 49-66.

Hayden, M. and Lam, Q.T. (2010), "Vietnam's higher education system”, in Harman, G., Hayden, M. and Pham, T.N. (Eds), Reforming Higher Education in Vietnam: Challenges and Priorities, Springer, New York, NY, pp. 15-30.

Hoang, L., Tran, L.T. and Pham, H. (2018), "Vietnam's government policies and practices in internationalization of higher education", in Tran, L.T. and Marginson, S. (Eds), Internationalisation in Vietnamese Higher Education, Springer, Dordrecht, pp. 19-42.

Hobson, P. and Josiam, B. (1996), "An integrated approach to internationalizing the hospitality and tourism curriculum in the USA", Journal of Transnational Management Development, Vol. 2 No. 1, pp. 13-34.

Huang, F. (2007), "Internationalisation of higher education in the developing and emerging countries: a focus on transnational higher education in Asia”, Journal of Studies in International Education, Vol. 11 Nos 3/4, pp. 421-432.

Khuong, C. (2015), "Internationalising tourism education in Vietnam: an evaluation of the work-integrated learning process in tourism training programs", doctor of philosophy thesis, RMIT University, Melbourne.

Knight, J. (2003), "Updating definition of internationalization”, International Higher Education and Training, Vol. 33, Fall, pp. 2-3.

Leask, B. (2001), "Bridging the gap: internationalizing university curricula", Journal of Studies in International Education, Vol. 5 No. 2, pp. 100-115.

Leask, B. (2009), “Internationalization, globalization and curriculum innovation”, in Hellsten, M. and Reid, A. (Eds), Researching International Pedagogies: Sustainable Practice for Teaching and Learning in Higher Education, Springer, Dordrecht, pp. 9-26.

Leask, B. (2015), Internationalizing the Curriculum, Routledge, London.

Merriam, S. (1998), Qualitative Research and Case Study Application in Education, Jossey-Bass Publishers, San Francisco, CA. 
HEED

12,1

MOET (2012), Quyết đinh số 711/QĐ-TTg, 13/6/2012, Chiến lươc phát triển giáo duc 2011-2020 (Decision number 711/QD-TTg, 13/6/2012, Strategies for Education Development 2011-2020), Hanoi.

Mok, K.H. and Yu, K.M. (2013), Internationlization of Higher Education in East Asia: Trend of Student Mobility and Impact on Education, Routledge, London.

Nguyen, P.M. (2011), "Decision approving 'Strategies for developing Vietnamese tourism up to 2020, a vision to 2030', available at: www.itdr.org.vn/details_news-x-187.vdl-bcth1 (accessed 21 June 2014).

Sangpikul, A. (2009), "Internationalization of hospitality and tourism higher education: a perspective from Thailand", Journal of Teaching in Travel \& Tourism, Vol. 9 Nos 1-2, pp. 2-20, doi: 10.1080/ 15313220903041964 .

Taylor, S. and Bogdan, R. (1998), Introduction to Qualitative Research Methods, 3rd ed., John Wiley, New York, NY.

Thao, L. (2012), "When will the quality of tourism ambassadors meet the standards?", available at: http://laodong.com.vn/Du-lich/Bao-gio-chat-luong-su-gia-cua-du-lich-dat-chuan/58050.bld (accessed 15 August 2014).

Tran, L.T. and Le, T.T.T. (2018), Teacher Professional Learning in International Education, Palgrave Macmillan, Basingstoke.

Tran, L.T. and Marginson, S. (2018), "Internationalisation of Vietnamese higher education: an overview", in Tran, L.T. and Marginson, S. (Eds), Internationalisation in Vietnamese Higher Education, Springer, Dordrecht, pp. 1-18.

Tran, L.T. and Nguyen, H.T. (2018), "Internationalisation of Vietnamese universities through using English as medium of instruction: practices, tensions and implications for local language policies", in Liyanage, I. (Ed.), Multilingual Education Year Book, Springer, Dordrecht, pp. 91-106.

Tran, L.T., Phan, H.T.T. and Marginson, S. (2018), "The 'advanced programmes' in Vietnam: internationalising the curriculum or importing the 'Best Curriculum' of the West?”, in Tran, L.T. and Marginson, S. (Eds), Internationalisation in Vietnamese Higher Education, Springer, Dordrecht, pp. 55-76.

Tran, L., Marginson, S., Do, H., Do, Q., Nguyen, N., Vu, T., Pham, T. and Nguyen, H. (2014), Higher Education in Vietnam: Flexibility, Mobility and Practicality in the Global Knowledge Economy, Palgrave Macmillan, New York, NY.

Vi, T. (2010), "Tourism human resources: Insufficient and unqualified", The Saigo n Times, available at: www.baomoi.com/Home/DuLich/www.thesaigontimes.vn/Nhan-luc-nganh-du-lich-con-thieu-vayeu/4642933.epi (accessed 21 June 2014).

Wood, R. (1997), "Tourism and the state: ethnic options and constructions of otherness", in Picard, M. and Wood, R. (Eds), Tourism, Ethnicity and the State in Asian and Pacific Societies, University of Hawaii Press, Honolulu, HI, pp. 1-34.

World Travel and Tourism Council (2015), "Travel \& tourism impact 2015-Vietnam”, London, available at: www.wttc.org/-/media/files/reports/economicimpact research/countries 2015/vietnam2015.pdf (accessed 5 January 2016).

Wright, S. and Lander, D. (2003), "Collaborative group interactions of students from two ethnic backgrounds", Higher Education Research and Development, Vol. 22 No. 3, pp. 237-252.

\section{About the authors}

Dr Cam Thi Hong Khuong is Lecturer at the Department of English for Work and Settlement, Bendigo Kangan TAFE, Australia. She obtained her PhD Degree in Social Studies at RMIT University, Australia. Her $\mathrm{PhD}$ research examined Tourism Education Programs in Higher Education and Vocational Training Education in Vietnam, focusing on work-integrated learning processes and internationalisation. Her research interests embrace internationalisation of education, teaching English as a second or foreign language, English for specific purposes and work-integrated learning. 
Ly Thi Tran is Associate Professor at the School of Education, Deakin University and Australian Research Council Future Fellow. Her research focuses on student mobility, international students across the school, VET and HE sectors and Vietnamese education. Ly has been awarded four grants on international education from the Australian Research Council. Ly's book, Teaching International Students in Vocational Education: New Pedagogical Approaches, won the International Education Association of Australia Excellence Award for Best Practice/Innovation in International Education. She has recently won the prestigious Future Fellowship from the Australian Research Council for her project, New Colombo Plan: Australian students' learning and engagement with Asia. Ly has produced over 150 publications (published or in press) in a wide range of outlets including books, edited research books, book chapters, refereed articles and conference papers. Ly Thi Tran is the corresponding author and can be contacted at: ly.tran@deakin.edu.au

For instructions on how to order reprints of this article, please visit our website: 